\title{
Obituaries
}

\author{
Editor: Henry R. Rollin
}

\section{ERIK ESSEN-MOLler, formerly Professor of Psychiatry, University of Lund, Sweden}

With the death, at age 91 of Erik Essen-Möller in Sweden (4 February 1901 to 12 November 1992), the original circle of founding fathers of modern, scientific psychiatric genetics has virtually disappeared. At the First International Congress of Psychiatry in Paris in 1950, despite the understandable and justified disgust of the scientific establishment over the fanatical abuse by the Nazis of human genetics, brave and humanitarian men presented empirical and theoretical papers to support the thesis that the role of genetic factors in understanding both normal and abnormal behaviour must be salvaged in order to serve all of humankind: Essen-Möller, along with F. J. Kallmann (USA), L. S. Penrose (UK), J. A. Fraser-Roberts (UK), E. Slater (UK), Ø. Ødegaard (Norway), and E. Strömgren (Denmark) risked their reputations and their careers by calmly presenting apolitical results relating genetic, biological, and environmental factors to behaviour.

Essen-Möller's intellectual pedigree traces back to Kraepelin via his two-year postdoctoral Rockefeller Fellowship in Munich (1931-1933) with Rüdin, as well as to one of the founders of quantitative genetics, Nilsson-Ehle, who was one of his professors at the University of Lund, where he obtained his BA in 1926 in genetics and statistics. His father Elis, a gynaecologist, sparked his interest in medicine and in the diagnosis of twins' zygosity; he published one of his earlier papers on the latter topic in a Festschrift for his father in 1930, the year before graduating from medical school in Lund, thereby initiating what would become major contributions to the mathematical genetics of paternity testing. Combining his growing enthusiasm for the study of psychiatry and personality with his love of genetics and statistics, he pursued the topic of the fertility of the mentally ill on his Munich Fellowship. He published his findings (in German) in 1934 as his dissertation (Habilitation) which showed that the fertility of schizophrenics was greatly diminished (and thus of no concern to eugenicists). In 1941 a book-length monograph (in German) detailed the results of his classical twin study of schizophrenia based on consecutive admissions to Swedish mental hospitals. He single-handedly examined $11 \mathrm{MZ}$ pairs and 27 SS DZ pairs, paying particular attention not only to clinical schizophrenia but also to what would now be called "schizophrenia spectrum disorders," preferring the German term Kreis (circle) as a more accurate one. Essen-Möller was influenced by $B$. Schulz and $H$. Luxenburger in his methodology and by Sjöbring (1879-1956) in his clinical acumen. He conducted a 30-year follow-up of his twin sample. After an academic start at the University of Lund, first as assistant professor of medical genetics and then of psychiatry, he became Chairman of Psychiatry at the Karolinska Institute in Stockholm briefly (1943-44) and then returned to Lund upon Sjöbring's retirement to serve as Chairman until 1967, when he "retired". Retired is in quotation marks to indicate that he only left behind the administrative chores, as his curiosity and productivity continued unabated until well into his $80 \mathrm{~s}$, when he had to enter a nursing home. Two volumes honour him for his scientific contributions - a Supplement (219:1970) to Acta Psychiatrica Scandinavica upon his retirement and Hummel \& Gerchow in dedication of his 80th birthday for his seminal role in the biomathmatics of paternity determination (Springer-Verlag, 1981). In 1985 he was honoured in New York with the Paul Hoch Medal from the American Psychopathological Association for his work in psychiatric genetic epidemiology: in 1947 Erik and three psychiatrist colleagues began to interview every inhabitant of two towns in Southern Sweden in a "conversational" and semi-structured format with the aim of describing and quantifying their psychopathology and personality variants within the personality theory of Sjöbring but informed by the ideas of Kretschmer, Schneider, Cattell, and Eysenck. In all, 2,550 individuals including 600 children were examined in depth; each clinician interviewed 12 subjects a day over the course of two summer months. The entire sample has been followed up after ten years and after 25 years, yet another landmark contribution to understanding the nature and nurture of individual differences in human behavior. Essen-Möller never passed by a good argument or the chance to promote the ideas of his mentor, Sjöbring, whose notions most observers found too opaque to follow.

Among the scientist-clinicians he mentored are $\mathrm{L}$. Kaij (a twin study of alcoholism), S. Dencker (a twin study of pairs discordant for closed head injuries), O. Hagnell (psychiatric epidemiology), and G. E. Nyman (personality variants). He was a close friend of Eliot Slater, who had followed in his footsteps as a Rockefeller Fellow in Munich in 1934 and through 
whom I first met him back in the early 1960s while doing my own postdoctoral fellowship in psychiatric genetics in London. Later my partner James Shields had the brilliant idea of inviting Essen-Möller (as well as Slater) to blindly diagnose our Maudsley twins using the orientation they each had preferred while conducting their own twin studies of schizophrenia before World War II. Thus began a long and warm (and sometimes feisty) friendship over 30 years of meetings at each other's homes, international meetings, and in detailed scientific correspondence. Erik went out of his way to be helpful and to instruct and influence in a firm but gentle manner. In his contribution to Slater's Festschrift (Gaskell, 1979) he shows his mastery over many complex issues within behavioural genetics that have yet to be resolved. He preferred some kind of a mixed-model to explain the transmission of schizophrenia and could come up with many reasons to be sceptical about multifactorial polygenic models. He can also be considered to be the father of the multiaxial system that has come to dominate psychiatric nosology, and he was one of the first to embarrass notions about "schizophrenogenic" mothering with strong empirical counterarguments.

Erik Essen-Möller led an exemplary life as teacher, researcher, clinician, and friend-we shall all miss him very much.

Dr Essen-Möller was elected FRC Psych(Hon) in 1967.

IRVING I. GOTTESMAN

\section{Robert Kellner, formerly Professor, Department of Psychiatry, University of New Mexico, Albuquerque, New Mexico}

Dr Robert Kellner, Vice-Chairman and Professor of the Department of Psychiatry at the University of New Mexico at Albuquerque, died on 15 November 1992, aged 70. He was particularly known for his work on hypochondriasis including his single-author volume, Somatization and Hypochondriasis (1986). He was a modest man and a very private person. He made light of his wartime experiences. Imprisoned twice before he was 17, he escaped from Czechoslovakia in 1939 , made his way to Greece and from there to North Africa, where he joined the British army and was decorated after the siege of Tobruk. He then came to Britain and flew as a rear gunner in a Czech bomber squadron stationed in Tain, Scotland. An accomplished photographer, he later published a fine book of wartime photographs. A committed social democrat, he returned to Czechoslovakia until 1948 when he was, once more, forced to escape his homeland. After receiving the Anatomy Prize at Charles University, he attended medical school at Liverpool University and graduated $\mathrm{MB}, \mathrm{ChB}$, in 1955 . He went into general practice in Chester and was an excellent family doctor. He managed to find time during this period to write a book on psychiatry in general practice (Family Ill Health, an investigation in general practice (1963). This was published by Tavistock Press and was the beginning of a thesis for his MD, PhD degrees, also obtained at Liverpool University.

Soon after, he took up psychiatry as a specialty and later decided to move because of his health. By this time, he had married his wife, Diana (MB, Liverpool, 1954), and they decided to emigrate to the United States. They settled in Albuquerque, where he thought the people and the system were sympathetic to the less fortunate in society. He never lost his concern for his fellow man. He was passionately against the death penalty and was intolerant of man's inhumanity to man wherever it took place. Unlike many who had been oppressed, he was never bitter and struggled on in his own way. He was a devoted and active member of Amnesty International and contributed both by his writings and donations. A keen chess player, he delighted in playing without a board and memorising the moves with his opponents. He was known to read a newspaper with his back to the board while instructing his opponent what his next move was. Bob had a marvellous sense of humour, frequently dry and occasionally unnoticed. He was one of a few people whose own laughter improved the telling of a story.

He was an excellent teacher (the Kellner Teaching Award honouring him was established in 1986), scientist, photographer, painter, chess player, raconteur, colleague, friend, father, and husband. In addition, a memorial symposium will be held annually in his honour. Bob is survived by his wife, Diana, and two sons, Thomas, physician, and Arthur, a neuropsychologist.

George M. SimpSON

\section{Erratum}

In the obituary for $\mathrm{Dr}$ Giuseppe Pampiglione (Psychiatric Bulletin, July 1993, 17, 443), Dr Pampiglione was wrongly described as being consultant psychiatrist at the Royal Free and at Charing Cross Hospital. Dr Pampiglione was in fact consultant neurophysiologist.

\section{The deaths of the following have also been reported:}

Daud Mahomed Bassa, formerly Consultant Psychiatrist; 64 Sandringham Avenue, Merton Park, London.

Alan Mervyn Edwards, 10 Sherrards Park Road, Welwyn Garden City, Herts AL8 7JP.

Henry Douglas Lamb, retired; 4449, Apartment 107, Meandering Way, Tallahassee, Florida 32308, USA.

Goal Megh Ras, Consultant Psychiatrist, Psychiatric Clinic, Punjabi Bagh, Patiala-147001, India. 